\title{
Economic analyses of onshore commercial large scale wind power plant installed in Turkey
}

\section{Türkiye'de kurulu olan kara tipi ticari ve büiülk ölçekli rüzgar güiç santralinin ekonomik analizleri}

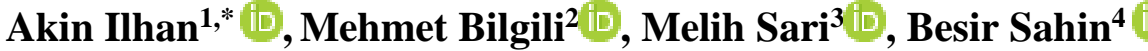 \\ ${ }^{l}$ Ankara Yildirim Beyazit University, Department of Energy Systems Engineering, Ankara, Turkey \\ ${ }^{2}$ Cukurova University, Department of Mechanical Engineering, Ceyhan, Adana, Turkey \\ ${ }^{3}$ Mustafa Kemal University, Building and Construction Office, Hatay, Turkey \\ ${ }^{4}$ Çukurova University,, Department of Mechanical Engineering, Sarıçam, Adana, Turkey
}

\begin{abstract}
In this study, the average wind conditions and economic analyses of four identical wind turbines of three-bladed and $3 \mathrm{MW}$ of rated power located in an installed wind farm abbreviated as WTPP and found in Eastern Mediterranean region of Turkey in Hatay province, were conducted. In this way, the probability density distributions based on wind directions regarding these identical wind turbines of the wind farm as well as cumulative probability density distributions regarding wind speeds for all identical wind turbines were performed. Besides, the economic analysis in terms of the present value calculation for a $3 \mathrm{MW}$ rated power wind turbine was executed, in which the results demonstrated that the application of the wind turbine project of this type would be profitable.
\end{abstract}

Keywords: Net present value, Payback period, Specific cost

\section{Introduction}

Energy is among the most significant and inevitable demands of the today's World. On the other hand, it certainly has a necessary item within the scope of the technological developments of countries, economic improvement, and above all, energy is very important in the human life [1-2]. Recently, the worldwide energy demand that is developing in parallel with the technological developments, population rise, and fossil fuel rapid depletion; has demonstrated a substantial increase [3-5]. The enhancement in energy consumption depends mainly on agents such as the population growth, the sustained improvement of the living standards, and the continuous industrialization of the developing countries. Towards 2030, a $21 \%$ rise in the worldwide energy demand will be definitely encountered. Besides currently, questions on climate change issues, alternative energy generation sources, emissions of greenhouse gases and reduction of the other worse effects to environment based on fossil fuels, have structured the most important problems of World's governments. To deal with these immediate problems directly, these topics are currently handled on the agenda of the World states.
Özet

$\mathrm{Bu}$ çalışmada; Türkiye'nin Doğu Akdeniz bölgesinde, Hatay șehrinde bulunan ve WTPP olarak kısaltılmıș kurulu bir rüzgar çiftliğinde yer alan, üç kanatlı ve 3 MW'lık nominal güce sahip dört özdeş rüzgar türbininin ortalama rüzgar koşulları ve ekonomik analizleri yapılmıştır. Bu çerçevede; rüzgar çiftliğinin, bu özdeş rüzgar türbinlerine ilişkin, rüzgar yönlerine göre olasılık yoğunluğu dağılımları ve aynı rüzgar türbinleri için, rüzgar hızlarına göre kümülatif olasılık yoğunluğu dağılımları, gerçekleştirilmiştir. Ayrıca, 3 MW'lık anma gücüne sahip bir rüzgâr türbinine, bugünkü değer hesaplaması yöntemiyle, ekonomik analiz uygulanmıştır ve elde edilen sonuçlar, bu tip rüzgâr türbini projesinin uygulanmasının karlı olacağını göstermiştir.

Anahtar kelimeler: Geri ödeme süresi, Net bugünkü değer, Spesifik maliyet

Because of the reason that conventional energy generation is not very economical today, besides due to the harmful environmental effects of energy utilization, and due to the continuously increasing energy demand of humanity, some troubles are associated in obtaining of the sustainable energy demand. As a result, an unsustainable situation occurs in current demand to energy when considered in terms of a global perspective including economic, environmental, human and climatic needs. Besides, to keep the $\mathrm{CO}_{2}$ emissions, which eventuate based on the energy generation, inside the specified limits, significance is required to be given principally to the renewable energy sources [6].

Wind energy is one of the most important types of renewable energy sources. In this regards, the comparison of the global wind installed capacity concerning the wind installed capacity of Turkey is presented in Figure 1, considering the years between 2000 and 2020. In this context, the global wind installed capacity has increased from 18,039 MW to 743,000 MW. However, the total wind power installations increased from 18.90 MW to 8,288 MW for the same period in Turkey.

\footnotetext{
* Sorumlu yazar / Corresponding author, e-posta / e-mail: akin.ilhan1983@gmail.com (A. Ilhan)

Geliș / Recieved: 22.01.2021 Kabul / Accepted: 04.08.2021 Yayımlanma / Published: 14.01.2022

doi: $10.28948 /$ ngmuh. 866312
} 


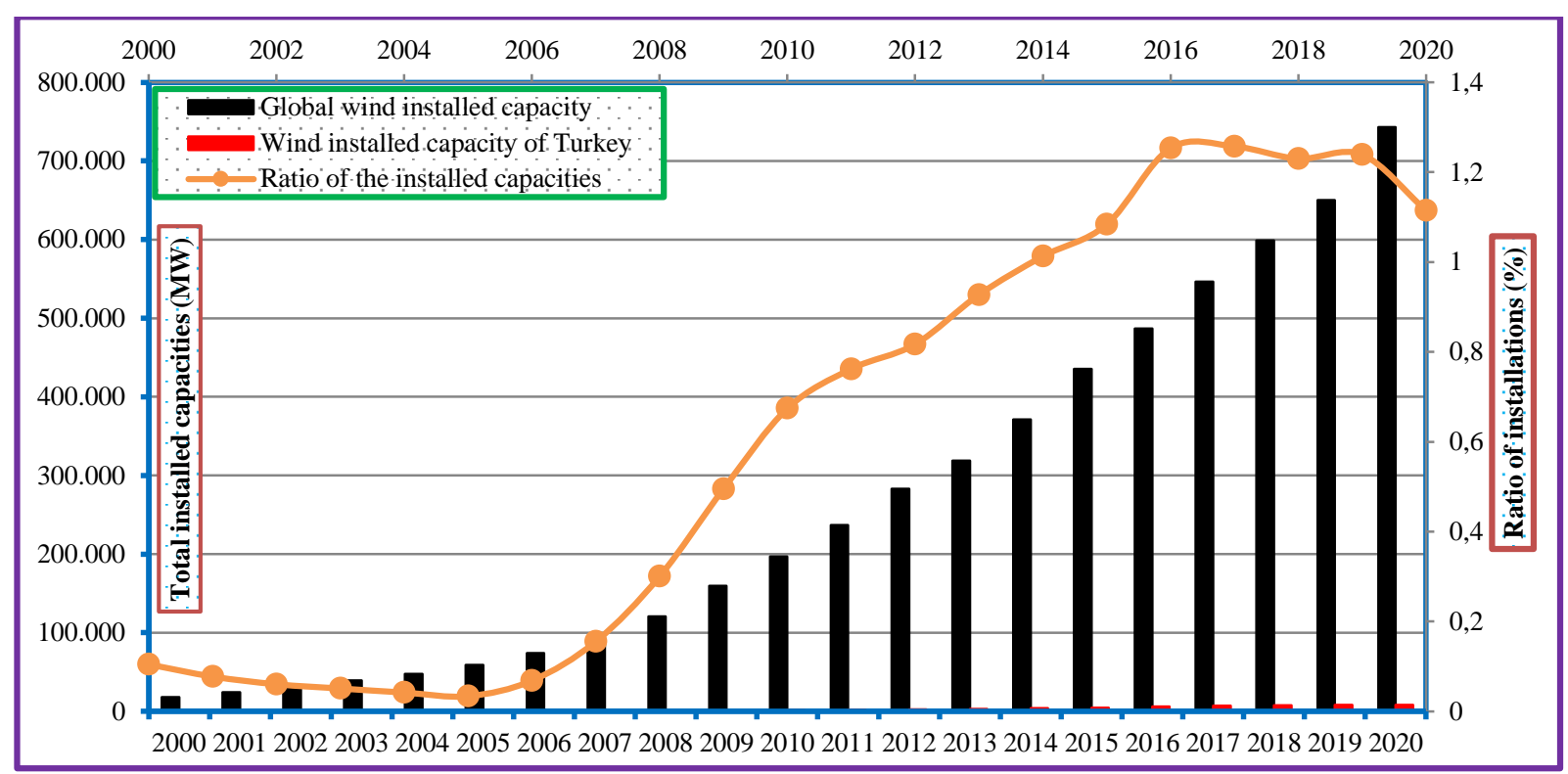

Figure 1. Total wind installed capacities of the World and Turkey

The ratio, determined according to the total wind power installations of Turkey divided by the global total wind power installations was $0.10 \%$ in 2000 , while this ratio in 2020 was calculated to be $1.12 \%$. Therefore, this study reveals that Turkey, compared to other countries in the World, performs good progress in terms of wind farm installations.

Turkey's growth of the energy demand indicated that the cumulative electricity generation of the country has risen from $94,861.7 \mathrm{GWh}$ to $305,168 \mathrm{GWh}$, considering the years between 1996 and 2020. In this regards, based on wind energy installations of the country by the end of 2020, 197 wind power plants were put into operation which corresponded a total installed wind power of $8.288 \mathrm{GW}$. So, $8.91 \%$ of the cumulative $93.0227 \mathrm{GW}$ installed power of Turkey was obtained from wind energy in terms of electrical energy production. Additionally, Turkey has the target to increase the wind energy share in electricity production to reach a total of $20 \mathrm{GW}$ at the end of 2023. However, only $41.44 \%$ of this goal has been accomplished. For this reason, around $11.7 \mathrm{GW}$ of additional wind power installations have been projected in the next three years. Considering this stipulated period, effective and conscious usage of wind energy potential, wind turbine technology improvement, an elaborate investigation of wind turbine aerodynamics and turbine performance characteristics, and advanced researches on economic analyses of wind turbines are very essential. In this study, initially, the average wind conditions for horizontal axis wind turbines located in an installed wind farm of WTPP were determined based on probability densities of wind blowing directions as well as based on probability densities of wind blowing speeds. This is followed by the economic analysis performed considering an identical wind turbine of the same farm.

\section{Materials and methods}

\subsection{The economic analysis concept}

\subsubsection{The cost of the wind energy conversion system}

Wind energy conversion system cost can be analyzed based on different elements of a total set of data including equipment costs (i.e., wind turbine cost, alternator cost, and tower cost), civil worker cost during the construction of the turbine or during the operating period, planning costs, project costs, grid connection costs, and other possible capital costs. Around $84 \%$ of the total installed cost of such a wind energy generation project involves these cited prominent costs. Accordingly, the total cost of a wind energy conversion system can be separated into sub-cost elements by defining the following major categories:

- The wind turbine costs: These costs comprehend generator, transformer, power converter, gearbox, rotary blades, tower and other possible costs.

- Civil work and worker costs: These costs include construction costs occurred during site preparation and the costs regarding tower foundations and payments of the personnel responsible for these works.

- Planning and project costs: These costs cover an important percentage of the total costs of a wind energy conversion system.

- Grid connection costs: These costs contain sub-costs of elements such as transformer costs, sub-station costs, and local distribution or transmission network connection costs.

- Other possible capital costs: The costs subsume road constructions inside the farm, buildings such as control rooms, and other auxiliary control systems, etc. 
The following figure presents the total cost analysis and related sub-cost shares considering a typical onshore wind turbine power plant. Besides, the proportions indicated in Figure 2 can alter with respect to the country, the project type, and also based on the utilized wind turbines. From this perspective, the used wind turbine costs, construction and civil works, grid connection costs, and other capital costs can vary in a range of percentage $64 \%$ to $84 \%, 4 \%$ to $16 \%, 9 \%$ to $14 \%$, and $4 \%$ to $10 \%$, respectively in which the estimated percentage values are obtained with reference to the total installed costs [7].

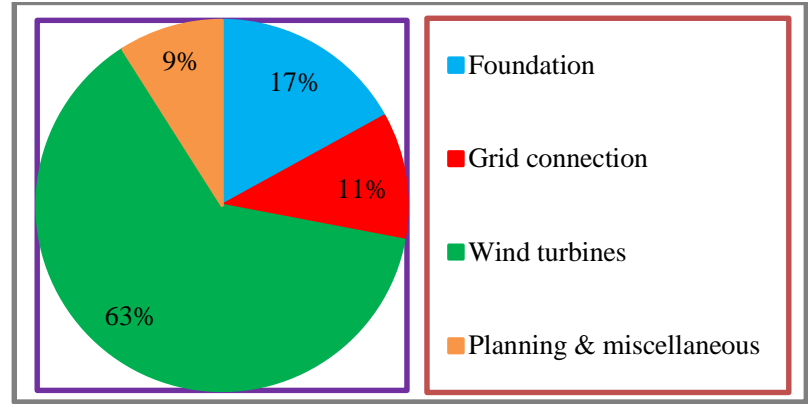

Figure 2. Analysis of the total cost during the installation process of a typical $3 \mathrm{MW}$ onshore wind turbine power plant [7]

\subsubsection{Simple payback period}

Measuring economic value of an investment is pursued by the basic and the most comprehensively used method referred to as the simple payback period. Based on the obtained benefits from an applied energy project; the payback period $(P B P)$ of the project is simply the number of years that the investment should face for it to become equal to the repayment of the total cost of the project. On the whole, the projects having the lowest payback period are chosen by the investors.

The equation below is used for the calculation of the PBP of an energy project,

$$
\operatorname{PBP}(\text { Years })=\frac{\text { Total initial investment }}{\text { Annual benefits with the current energy costs }}
$$

The interest rate and the economic life are not considered in the simple payback period, which is the primary inconvenience of this method. Even so, this method can be utilized in cases having many risks and uncertainties for the future.

\subsubsection{The net present value of the wind power farm project}

The Net Present Value (NPV) method is used to conduct the wind turbine economic analysis of a $3 \mathrm{MW}$ rated power, $P_{r}$ wind turbine located in the WTPP.

A wind project NPV is the value of all incomes which are discounted to the beginning of the investment. The NPV is taken into account by subtracting the initial investment in the calculations. In Equation (2), the real rate of interest is defined by " $r$ " demonstrating the sum of the discount rate, $i$ and the inflation rate, $s$ for this estimation. The discount rate (i) is selected based on the cost and the available capital source, taking a balance between equity and the debt financing into account as well as performing an estimate of the financial risks entailed in the wind project. So, the real rate of the interest $(r)$ can be characterized as presented in Equation (2) shown below [8]:

$$
\text { Real rate of interest }(r)=\text { Discount rate }(i)+\text { Inflation rate }(s)
$$

Equation (2) was utilized in order to evaluate future income and expenditures. Besides, first yearly income $\left(P_{1}\right)$ is taken and divided by $(1+\mathrm{r})^{1}$ term for the calculation of the net present value, in which the worth of the yearly incomes is denoted by $\mathrm{P}_{\mathrm{j}}$, which has the set of yearly income values between $(1,2,3,4, \ldots, n)$. In the presence of the second yearly income; the net present value is computed in addition to the procedure applied to the first yearly income plus the second yearly income divided by $(1+r)^{2}$. In this manner, in the cases of third income, fourth income, and the $\mathrm{n}^{\text {th }}$ income, the divisions by $(1+\mathrm{r})^{3},(1+\mathrm{r})^{4}$, and $(1+\mathrm{r})^{\mathrm{n}}$ terms are executed, respectively. Consequently, the net present value is computed by summing up whole cited terms together to the initial investment [8]:

$$
\text { Net present value }=\frac{P_{1}}{(1+r)^{1}}+\frac{P_{2}}{(1+r)^{2}}+\cdots+\frac{P_{n}}{(1+r)^{n}}
$$

With the Net Present Value $(N P V)$, those parameters including initial investment capital, maintenance cost, annual running cost, annual savings, and the salvage value of the wind turbine can be considered. Accordingly, the profitability of a wind turbine project can be evaluated in terms of obtaining a clear idea for the investor. Equation (4) presented below can be utilized for the expression of the cited method using another equation,

$$
\text { Net Present Value }=\sum_{m=m+1}^{t} \frac{F_{n}}{(1+i)^{n}}-\sum_{n=0}^{m} \frac{M_{n}}{(1+i)^{n}}
$$

In a wind project, the terms designated by $M_{n}, F_{n}, m, t-m$, and $i$ are the cost, revenue on the $n^{\text {th }}$ year, the year that the investment completed, wind project economic life, and the discount rate, respectively.

Considering these explanations, if the NPV value is greater than 0 , the forecasted wind project can be taken into account as an economically acceptable project. Additionally, when it is required to pick a single project among a large number of wind projects, the one having the highest net present value is chosen [9].

\subsubsection{Real rate of return}

The real rate of return is defined according to the value of the real rate of interest, $r$ making the wind project net present value at precisely zero. On a given investment, the real rate of return is a measure of the real interest rate which is earned. Besides, if the $N P V>0$ : The considered project will have a real rate of return being higher than the real rate of interest, $r$. On the other hand, if the $N P V<0$ : The project will have a lower rate of return.

An iterative procedure should be followed in order to find the roots of the expression for the present value which is required for the estimation of the real rate of return. One 
approach is to make a forecast that is substituted into the equation. In the case of the guess to be so high, the net present value will be negative. On the other hand, in the case of the guess to be so low, the net present value will be positive [8].

\subsubsection{Wind turbine present value cost analysis}

An initiative has been performed regarding the estimation of the present value cost analysis for the electricity cost considering twenty years of wind turbine project duration. For the calculation of the present value, initially, we must know the wind turbine project investment. Consequently, total wind turbine cost is obtained as demonstrated below:

Total turbine cost $=$ Turbine cost + Installation cost

The "installation cost" shown in Equation (5) can be accepted as 0.30 of the wind turbine price [8].

Based on the central aspect of the analysis, the payments which include the initial payment as well, are used for the calculation of the net present value and the real rate of return over 20 years of the project lifetime. And in this analysis, the tax payments, credits, and depreciation credits are not taken into account.

Wind turbine project total expenditure is characterized as shown below,

Total expenditure

= Total turbine cost

+ Operation and maintenance cost over the expected lifetime

In this analysis, the operation and maintenance cost can be taken as a fixed amount for each year or with respect to a percentage of the wind turbine cost. This situation may also cover a service contract signed with the turbine manufacturer company. In the current study, the operation and maintenance costs were taken to be $1.5 \%$ of the wind turbine price [8].

For the definition of the net income for each year, the electricity price and the gross yearly income obtained from electricity sales are needed to be known. In this context, the gross yearly income gained from the electricity sale can be acquired as demonstrated below in Equation (7):

Gross yearly income from electricity sale

$=$ Energy produced in a year $x$ Price of electricity

In Equation (7), energy production is given by, N.C $.8760 . \mathrm{P}_{\mathrm{r}}$, where $N$ is the number of turbines, $C_{p}$ is the capacity factor, 8760 is the number of hours in one year, and $P_{r}$ is the rated power of the turbine. Hence, the net income per year is formulated as shown in Equation (8) below,

$$
\begin{aligned}
& \text { Net income stream per year } \\
& =\text { Gross yearly income from electricity sale } \\
& \text { - Operation and maintenance cost per year }
\end{aligned}
$$

Eventually, Equations (9) and (10) can respectively be obtained for the yearly net real rate of return and the present value of electricity per $\mathrm{kWh}$.
Yearly net real rate of return
$=\frac{\text { Net present value of income stream }}{\text { Total turbine cost }} \cdot \frac{1}{\text { Project lifetime }}$

Present value of electricity per $\mathrm{kWh}$

$=\frac{\text { Net present value of income stream }}{\text { Yearly energy production. Project lifetime }}$

\section{Results and discussions}

\subsection{Results for wind condition and economic analysis of WTPP}

In this part of the study, the horizontal axis wind turbine one-year data obtained from an existing wind farm in Hatay province of Turkey was used. The technical characteristics of the VESTAS V90-3.0 MW identical wind turbines of the farm are demonstrated in Table 1 [10]. These wind turbines have main specific characteristics of rated power $\left(P_{r}\right)$, rotor diameter $\left(D_{\text {rotor }}\right)$, rotor swept area $\left(A_{d}\right)$, hub-height, number of blades $(n)$, nominal turbine rotor rotational speed corresponding to $3 \mathrm{MW}, 90 \mathrm{~m}, 6,362 \mathrm{~m}^{2}, 80 \mathrm{~m}, 3,16.10 \mathrm{rpm}$, respectively. The measured data regarding four identical wind turbines of WTPP was used in the considered year. These identical wind turbines have been symbolized as $W T$ $1, W T-2, W T-3$, and WT-4 [10].

Table 1. The technical specifications of four identical wind turbines located in WTPP [10]

\begin{tabular}{lc}
\hline \multicolumn{1}{c}{ Features of wind turbines } & Specification \\
\hline Rotor diameter $\left(D_{\text {rotor }}\right)$ & $90 \mathrm{~m}$ \\
Rotor swept area $\left(A_{d}\right)$ & $6,362 \mathrm{~m}^{2}$ \\
Number of blades $(n)$ on the route & 3 \\
Nominal turbine rotor rotational speed & $16.10 \mathrm{rpm}$ \\
Hub height (tower height) & $80 \mathrm{~m}$ \\
Blade length & $44 \mathrm{~m}$ \\
The wind speed at which the turbine begins to turn & $4 \mathrm{~m} / \mathrm{s}$ \\
(cut-in wind speed) & $25 \mathrm{~m} / \mathrm{s}$ \\
Turbine shutdown or cut-out wind speed & $3 \mathrm{MW}$ \\
Turbine rated power $\left(P_{r}\right)$ & $50 \mathrm{~Hz}$ \\
Frequency & $1000 \mathrm{~V}$ \\
The output voltage from the generator &
\end{tabular}

\subsubsection{Results of average wind condition analysis of WTPP}

The discussions on wind direction and wind speed analyses were performed considering the literature studies based on the statistical methods [11-15]. Considering wind direction data as well as wind speed data obtained from studied WTPP, initially, the demonstration of Figures 3 and 4 was executed as presented below. In these regards, considering four identical wind turbines of the WTPP, while Figure 3 shows the probability densities $(P D)$ with respect to the wind directions; Figure 4 indicates the cumulative probability densities $(C P D)$ as a function of wind speeds.

By the examination of four equivalent wind turbine annual data; probability density $(P D)$ presented in Figure 3 demonstrates the dominant wind direction in which the wind is most likely to blow most of the time. North and south directions have been respectively indicated by 0 degree and 180 degree based on the general wind direction assumption. As clearly seen in this figure, peak values of the probability densities $(P D)$ of the wind directions occur firstly at 330 degree and secondly at 120 degree. 


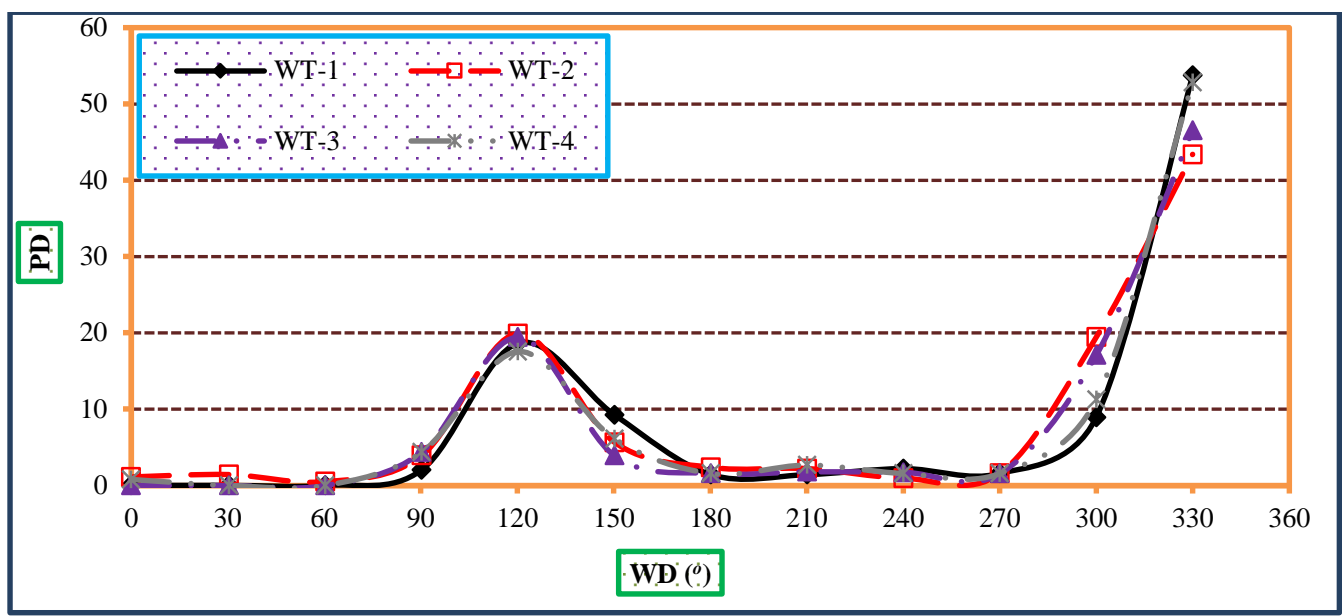

Figure 3. PD distributions based on wind directions for four identical wind turbines of WTPP

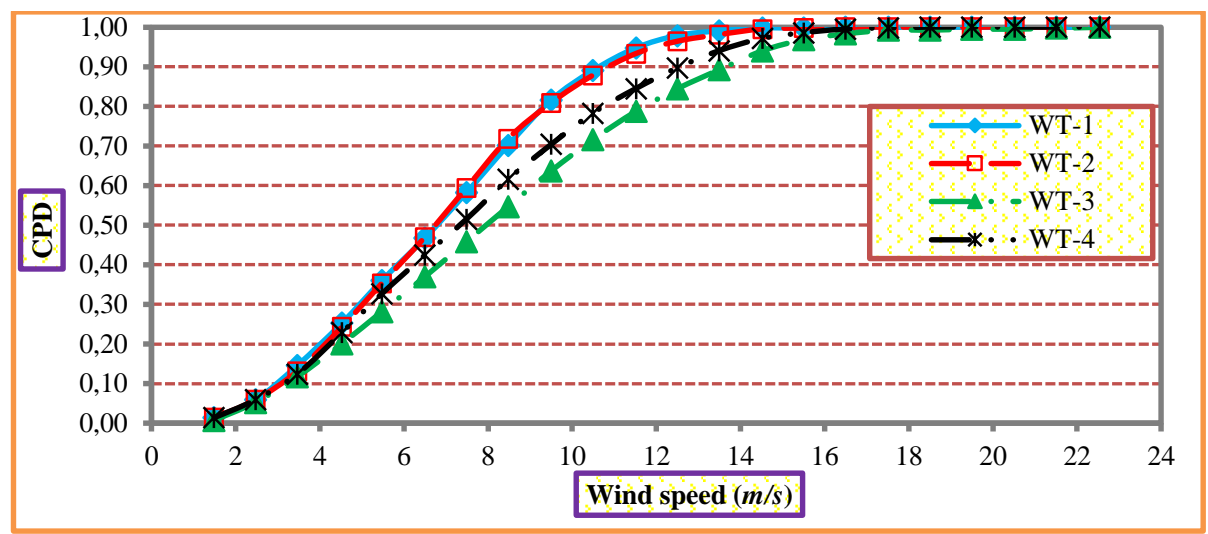

Figure 4. CPD distributions based on wind speed for four identical wind turbines of WTPP

These results declare that wind in this WTPP generally blows from the directions of east-southeast and north-northwest.

Besides, the cumulative probability density $(C P D)$ presented in Figure 4 supplies information regarding wind speed density distributions to which the wind turbines are exposed. Analysis of this figure reveals that hourly wind speeds in this wind farm are higher than $4 \mathrm{~m} / \mathrm{s}$ in about $80 \%$ of the occasions. Similarly, considering wind turbines $W T-1$, $W T-2, W T-3$, and $W T-4$, respectively; hourly wind speeds in this farm are less than $10 \mathrm{~m} / \mathrm{s}$ at the percentage values of approximately $89 \%, 88 \%, 72 \%$, and $78 \%$ of the occasions.

On the other hand, it is possible to divide the free stream $\left(U_{\infty}\right)$ magnitude into three regions of value ranges, i.e.,

- Region 1: $3 \mathrm{~m} / \mathrm{s} \leq U_{\infty} \leq 5 \mathrm{~m} / \mathrm{s}$, region of low wind speeds,

- Region 2: $5 \mathrm{~m} / \mathrm{s} \leq U_{\infty} \leq 10 \mathrm{~m} / \mathrm{s}$, region of moderate wind speeds,

- Region 3: $10 \mathrm{~m} / \mathrm{s} \leq U_{\infty} \leq 25 \mathrm{~m} / \mathrm{s}$, region of high wind speeds.

\subsubsection{Results of economic analysis of a $3 \mathrm{MW}$ wind turbine of the WTPP}

In the analysis of the electricity cost obtained from the wind turbine, it is suitable to perform the following assumptions: For whole wind turbines, the useful lifetime was accepted to be twenty (20) years, the operation and maintenance costs were adopted regarding the turbine cost as $1.5 \%$ of the cost; and the real rate of interest $(r)$ was also determined to be convenient based on the wind turbine cost and marketing conditions to be taken as $7 \%$.

The gross average yearly income obtained from the electricity sale and the net average income per year were determined as 947,014 \$/year and 887,014 \$/year, respectively, under the wind turbine cost, the installation cost, the operation and maintenance costs, and the price of electricity of 4,000,000 \$, 1,200,000 \$, 60,000 \$/year, and $0.099 \$ / \mathrm{kWh}$, respectively. The gross yearly income and the net income per year have been indicated as mean values per year. The reason is that 30 hours, 20 hours, 15 hours, 5 hours, and 7 hours maintenance have been performed to the turbine by stopping it, by $2^{\text {nd }}, 3^{\text {rd }}, 8^{\text {th }}, 13^{\text {th }}$, and $19^{\text {th }}$ years, respectively.

The stopping times of the turbine and in which years and for how long it was stopped were presented to us with the attached list. Since, the wind turbine didn't produce the same amount of electricity every year, some variations in the gross yearly income and net income per year occurred. Besides, the capacity factor of wind power plant has been determined to be equal to $C_{p}=0.36416$. 
Table 2. The present value calculation conducted considering a wind turbine of $3 \mathrm{MW}$ rated power $\left(P_{r}\right)$

\begin{tabular}{|c|c|c|c|c|c|}
\hline $\begin{array}{c}\text { Year } \\
\mathbf{n}\end{array}$ & $\begin{array}{c}\text { Expenditures } \\
\$\end{array}$ & $\begin{array}{c}\text { Gross income } \\
\$\end{array}$ & $\begin{array}{c}\text { Net income } \\
(\mathbf{P}) \\
\$\end{array}$ & $\begin{array}{c}\text { Present value factor } \\
1 /(1+r)^{n} \\
r=0.07\end{array}$ & $\begin{array}{c}\text { The net present value } \\
\text { of income } \\
\$\end{array}$ \\
\hline 0 & $-5,200,000$ & - & - & - & - \\
\hline 1 & $-60,000$ & 947,430 & 887,430 & 0.93458 & $\frac{P_{1}}{(1+r)^{1}} 829,373.83$ \\
\hline 2 & $-60,000$ & $944,185.38$ & $884,185.38$ & 0.87344 & $\frac{P_{2}}{(1+r)^{2}} 772,281.75$ \\
\hline 3 & $-60,000$ & $945,266.92$ & $885,266.92$ & 0.81630 & $722,641.51$ \\
\hline 4 & $-60,000$ & 947,430 & 887,430 & 0.7629 & $677,016.10$ \\
\hline 5 & $-60,000$ & 947,430 & 887,430 & 0.71299 & $632,725.33$ \\
\hline 6 & $-60,000$ & 947,430 & 887,430 & 0.66634 & $591,332.08$ \\
\hline 7 & $-60,000$ & 947,430 & 887,430 & 0.62275 & $552,646.80$ \\
\hline 8 & $-60,000$ & $945,807.69$ & $885,807.69$ & 0.58201 & $515,548.14$ \\
\hline 9 & $-60,000$ & 947,430 & 887,430 & 0.54393 & $482,703.12$ \\
\hline 10 & $-60,000$ & 947,430 & 887,430 & 0.50835 & $451,124.41$ \\
\hline 11 & $-60,000$ & 947,430 & 887,430 & 0.47509 & $421,611.60$ \\
\hline 12 & $-60,000$ & 947,430 & 887,430 & 0.44401 & $394,029.53$ \\
\hline 13 & $-60,000$ & $946,889.23$ & 886,889 & 0.41496 & $368,027.50$ \\
\hline 14 & $-60,000$ & 947,430 & 887,430 & 0.38782 & $344,160.65$ \\
\hline 15 & $-60,000$ & 947,430 & 887,430 & 0.36245 & $321,645.47$ \\
\hline 16 & $-60,000$ & 947,430 & 887,430 & 0.33873 & $300,603.24$ \\
\hline 17 & $-60,000$ & 947,430 & 887,430 & 0.31657 & $280,937.61$ \\
\hline 18 & $-60,000$ & 947,430 & 887,430 & 0.29586 & $262,558.52$ \\
\hline 19 & $-60,000$ & $946,672.92$ & 886,673 & 0.27651 & $245,172.45$ \\
\hline 20 & $-60,000$ & 947,430 & 887,430 & 0.25842 & $229,328.78$ \\
\hline Total & $-6,400,000$ & $18,940,272$ & $17,740,272$ & - & $9,395,468$ \\
\hline
\end{tabular}

Considering this value of the capacity factor as well as Equation (7), the economic analysis has been performed.

The wind turbine cost of 4,000,000 $\$$ for the considered $3 \mathrm{MW}$ wind turbine is reported to be at the same level compared with the values found in the literature of the identical.

On the other hand, for a wind turbine of $3 \mathrm{MW}$ rated power $\left(P_{r}\right)$ of this wind farm: The results of the present value calculation has been demonstrated in Table 2 .

Utilization of Equations (8) and (9) yielded that while the yearly net real rate of return was calculated to be 9.0341 percent/year, whereas the present value of electricity per $\mathrm{kWh}$ was determined to be $0.004211 \$ / \mathrm{kWh}$.

Explicit information has been reached considering the profitability of the wind project with the utilization of the Net Present Value method. When a $3 \mathrm{MW}$ rated power $\left(P_{r}\right)$ wind turbine of this wind farm is studied, the revenues and the costs were calculated as $18,940,272 \$$ and $6,400,000 \$$, respectively, under the initial investment capital (turbine specific cost), the annual running cost, the operation and maintenance costs, the annual savings, and the salvage value corresponding to $4,000,000 \$, 320,000 \$, 60,000$ \$/year,
$894,807 \$$, and $625,000 \$$, respectively. Utilization of Equation (3) indicated that the net present value $(N P V)$ of the wind turbine project was calculated as 9,395,468 \$. These calculations indicated that the PBP of the project has been reported as 5.86 years. Within the light of this information and the above calculations, it will be correct to say that the application of this wind turbine project has been reported to be profitable.

\section{Conclusions}

In this study, average wind conditions in terms of wind blowing direction and wind speed probability distributions of four equivalent wind turbines of $3 \mathrm{MW}$ rated power and located in an installed wind farm of Hatay province of Turkey, abbreviated as WTPP were initially investigated. Besides, economic analysis of a $3 \mathrm{MW}$ rated power wind turbine which is located in this WTPP has been conducted:

Based on the probability density function performed with respect to the wind blowing direction, the wind in this WTPP has been reported to mostly blow firstly at 330 degree and secondly at 120 degree, corresponding to approximately $50 \%$ and $20 \%$ of probability densities, respectively. Namely, it has been conducted that wind turbines in the WTPP were 
mostly subjected to wind at geographical directions of firstly north-northwest and, secondly, east-southeast directions. In this regards, it has been conducted that wind regime in this region has non-variable and steady characteristics. Besides, wind speeds in this wind farm were reported to be higher than $4 \mathrm{~m} / \mathrm{s}$ in about $80 \%$ of the occasions. Similarly, hourly wind speeds in this farm were reported to be less than $10 \mathrm{~m} / \mathrm{s}$ at approximately $89 \%, 88 \%, 72 \%$, and $78 \%$ of the occasions considering $W T-1, W T-2, W T-3$, and $W T-4$, respectively. In this context, based on the free-stream wind speed value ranges, the wind blowing magnitude in the WTPP has been reported to be in Region 2.

When a $3 \mathrm{MW}$ rated power wind turbine of WTPP is considered, based on the calculations of expenditures including calculations of wind turbine cost, the installation cost, economic life, salvage value and the operation and maintenance costs; as well as considering the calculations on the gross income, including the study for the price of electricity, net income; and the net present value calculations including the real rate of interest $(r)$ calculations as well, it has been observed that the application of such wind turbine project would be profitable. These calculations revealed that the PBP of the project was estimated as 5.86 years.

\section{Conflicts of interest}

No conflict of interest was declared by the authors.

\section{Similarity rate (iThenticate): $14 \%$}

\section{References}

[1] Y.A. Kaplan, Overview of wind energy in the World and assessment of current wind energy policies in Turkey. Renewable and Sustainable Energy Reviews, 43, 562-568, 2015. https://doi.org/10.1016/ j.rser.2014.11.027.

[2] J. Waewsak, M. Landry and Y. Gagnon, Offshore wind power potential of the gulf of Thailand. Renewable Energy, 81, 609-626, 2015. https://doi.org/ 10.1016/j.renene.2015.03.069.

[3] G. Emmanouil, G. Galanis, C. Kalogeri, G. Zodiatis and G. Kallos, 10-year high resolution study of wind, sea waves and wave energy assessment in the Greek offshore areas. Renewable Energy, 90, 399-419, 2016. https://doi.org/10.1016/j.renene.2016.01.031.
[4] A. Korompili, Q. Wu and H. Zhao, Review of VSC HVDC connection for offshore wind power integration. Renewable and Sustainable Energy Reviews, 59, 14051414, 2016. https://doi.org/10.1016/j.rser.2016.01.064.

[5] P. Söderholm and M. Pettersson, Offshore wind power policy and planning in Sweden. Energy Policy, 39, 518525, 2011.https://doi.org/10.1016/j.enpol.2010.05.065.

[6] C.W. Zheng, C.Y. Li, J. Pan, M.Y. Liu and L.L. Xia, An overview of global ocean wind energy resource evaluations. Renewable and Sustainable Energy Reviews, 53, 1240-1251, 2016. https://doi.org/ 10.1016/j.rser.2015.09.063.

[7] International Renewable Energy Agency, 2013. http://www.irena.org.

[8] M. Ragheb, Economics of wind energy. National Geographic, March 2017.

[9] S. Mathew, Wind Energy Fundamentals, Resource Analysis and Economics. Springer, Netherland, 2006.

[10] Vestas. http://www.vestas.com, Accessed 24 July 2021.

[11] G. Huang, L. Peng, Y. Su, H. Liao and M. Li, A wireless high-frequency anemometer instrumentation system for field measurements. Wind and Structures, 20(6), 739-749, 2015. http://dx.doi.org/10.12989/ was.2015.20.6.739.

[12] S.S. Law, J.Q. Bu, X.Q. Zhu and S.L. Chan, Wind characteristics of Typhoon Dujuan as measured at a 50 m guyed mast. Wind and Structures, 9(5), 387-396, 2006. http://dx.doi.org/10.12989/was.2006.9.5.387.

[13] Q.S. Li, L. Zhi and F. Hu, Field monitoring of boundary layer wind characteristics in urban area. Wind and Structures, 12(6), 553-574, 2009. https://doi.org/ 10.12989/was.2009.12.6.553.

[14] G. Solari, M. Burlando, P. De Gaetano and M.P. Repetto, Characteristics of thunderstorms relevant to the wind loading of structures. Wind and Structures, 20(6), 763-791, 2015. http://dx.doi.org/10.12989/ was.2015.20.6.763.

[15] H. Wang, T. Tao and T. Wu, Wind power spectra for coastal area of East Jiangsu Province based on SHMS. Wind and Structures, 22(2), 235-252, 2016. http://dx.doi.org/10.12989/was.2016.22.2.235. 